Article

\title{
Investigation and Modeling of Gas-Liquid Mass Transfer in a Sparged and Non-Sparged Continuous Stirred Tank Reactor with Potential Application in Syngas Fermentation
}

\author{
Kan Liu ${ }^{1}$, John R. Phillips ${ }^{1}$, Xiao Sun ${ }^{1}{ }^{\mathbb{D}}$, Sayeed Mohammad ${ }^{2}$, Raymond L. Huhnke ${ }^{1}$ \\ and Hasan K. Atiyeh 1,* \\ 1 Department of Biosystems and Agricultural Engineering, Oklahoma State University, \\ Stillwater, OK 74078, USA \\ 2 School of Chemical Engineering, Oklahoma State University, Stillwater, OK 74078, USA \\ * Correspondence: hasan.atiyeh@okstate.edu; Tel.: +1-405-744-8397
}

Received: 21 June 2019; Accepted: 9 August 2019; Published: 13 August 2019

\begin{abstract}
Syngas (mixture of $\mathrm{CO}, \mathrm{H}_{2}$ and $\mathrm{CO}_{2}$ ) fermentation suffers from mass transfer limitation due to low solubility of $\mathrm{CO}$ and $\mathrm{H}_{2}$ in the liquid medium. Therefore, it is critical to characterize the mass transfer in syngas fermentation reactors to guide in delivery of syngas to the microorganisms. The objective of this study is to measure and predict the overall volumetric mass transfer coefficient, $k_{\mathrm{L}} a$ for $\mathrm{O}_{2}$ at various operating conditions in a 7-L sparged and non-sparged continuous stirred-tank reactor (CSTR). Measurements indicated that the $k_{\mathrm{L}} a$ for $\mathrm{O}_{2}$ increased with an increase in air flow rate and agitation speed. However, $k_{\mathrm{L}} a$ for $\mathrm{O}_{2}$ decreased with the increase in the headspace pressure. The highest $k_{\mathrm{L}} a$ for $\mathrm{O}_{2}$ with air sparged in the CSTR was $116 \mathrm{~h}^{-1}$ at $600 \mathrm{sccm}, 900 \mathrm{rpm}, 101 \mathrm{kPa}$, and $3 \mathrm{~L}$ working volume. Backmixing of the headspace $\mathrm{N}_{2}$ in the sparged CSTR reduced the observed $k_{L} a$. The mass transfer model predicted the $k_{\mathrm{L}} a$ for $\mathrm{O}_{2}$ within $10 \%$ of the experimental values. The model was extended to predict the $k_{\mathrm{L}}$ a for syngas components $\mathrm{CO}, \mathrm{CO}_{2}$ and $\mathrm{H}_{2}$, which will guide in selecting operating conditions that minimize power input to the bioreactor and maximize the syngas conversion efficiency.
\end{abstract}

Keywords: mass transfer; sparged and non-sparged CSTR; pressure and backmixing effects; syngas fermentation; modeling

\section{Introduction}

Liquid biofuels (e.g., bioethanol and biobutanol) can be produced from lignocellulosic feedstocks using biochemical or hybrid thermochemical-biological processes, which alleviates the heavy dependence on crude oil and avoid competition with food crops [1,2]. Biochemical conversion platform of lignocellulosic biomass to biofuels requires pretreatment, enzymatic hydrolysis, and detoxification of hydrolysate to obtain fermentable sugars (i.e., glucose and xylose) before fermentation, resulting in energy intensive and economically unfavorable processing [3]. The hybrid process involves gasification of lignocellulosic feedstocks to synthesis gases (syngas, mixture of $\mathrm{CO}, \mathrm{H}_{2}$ and $\mathrm{CO}_{2}$ ) regardless of biomass composition and origin, followed by fermentation of syngas to biofuel [4]. Based on a process simulation model, the hybrid process has the potential to produce biofuels with higher yield from same amount of biomass compared to biochemical platform [5]. This process can achieve $440 \mathrm{~L}$ ethanol/Mg biomass compared to $340 \mathrm{~L}$ ethanol/Mg biomass in the biochemical platform due to utilization of all components of the biomass, including lignin, to make ethanol [6]. 
Microbial catalysts such as Clostridium carboxidivorans, Alkalibaculum bacchi, Clostridium ragsdalei and Clostridium ljungdahlii have been used in the production of ethanol, butanol and hexanol from syngas [7-10]. One bottleneck during syngas fermentation is gas-liquid mas transfer limitation due to the low solubility of the gaseous substrates $\mathrm{CO}$ and $\mathrm{H}_{2}$ in the liquid medium [11]. Mass transfer limitations occur when cells have the capacity to process more gas than the bioreactor can supply. The resistance of gaseous substrate diffusion at the gas-liquid interface was recognized as the limiting step in syngas fermentation $[12,13]$. Gaseous substrate mass transfer limitation results in low cell concentration and low productivity, making the process not economically feasible [14]. Therefore, it is necessary to characterize and model the mass transfer in the bioreactor used for syngas fermentation to understand how to overcome mass transfer limitation of the gaseous substrates, $\mathrm{CO}$ and $\mathrm{H}_{2}$. In addition, modeling improves understanding of the process behavior and assists in bioreactor design, process control and optimization of operating conditions to maximize productivity and reduce costs to meet the requirements for commercial fermentation [5].

The mass transfer characteristics of several types of bioreactors, including the continuously stirred tank reactor (CSTR), trickle bed reactor (TBR), hollow fiber membrane reactor (HFR), bubble column reactor (BCR), monolith biofilm reactor (MBR), horizontal rotating packed bed biofilm (h-RPB) reactor, and airlift reactor have been reported [11,13,15-19]. These studies estimated the volumetric mass transfer coefficient via an air-water system, or sparging syngas into medium with and without fermentation. The HFR and TBR were reported to have higher volumetric mass transfer coefficients $\left(k_{\mathrm{L}} a\right)$ than the CSTR. Besides, the effect of internal pressure and gas/liquid interface area on the CO mass transfer rate in an HFR was investigated and an increase in CO mass transfer rate was observed [20]. Another study reported that for syngas fermentation in an external HFR, the membrane surface area was found to be the most significant factor in the enhancement of $\mathrm{CO}$ mass transfer rates [21].

Recently, a new model predicting $k_{\mathrm{L}} a$ of $\mathrm{CO}$ and $\mathrm{H}_{2}$ in a HFR had also been developed [22]. However, when considered for syngas fermentation, each reactor has its own advantages and disadvantages in terms of operation and scale up [15]. The CSTR, as a conventional reactor, has been more extensively studied and applied in industrial fermentation processes than the HFR and TBR [11,15]. In addition, the CSTR operation is simpler than other types of reactors and can provide good mixing capability and high mass transfer rates, but requires high power consumption, which becomes an issue for large reactors due to high power cost. Moreover, the HFR operation can suffer from membrane fouling, and the pump for liquid recirculation requires external power input $[15,23,24]$. The TBR increases gas and liquid contact by forming a thin liquid film on the packing; however, an external pump is required to circulate the liquid to the TBR $[15,17]$. Issues related to scale up and operation parameters of various bioreactors for syngas fermentation have been recently addressed [13,15,25-27].

Most mass transfer studies in syngas fermentation using CSTR investigated operating parameters such as gas flow rate and agitation speed at a fixed working volume and mostly in unpressurised reactors $[15,28,29]$. Only a few studies have investigated the effect of elevated pressure on the mass transfer rates in a bioreactor. The effect of increased air pressure on the $\mathrm{O}_{2}$ mass transfer rate in a stirred bioreactor was studied and a correlation has been presented [30,31]. $\mathrm{CO}$ and $\mathrm{H}_{2}$ solubility and the driving force for mass transfer increase with elevated $\mathrm{CO}$ and $\mathrm{H}_{2}$ partial pressures in the headspace [12]. The incorporation of various liquid working volumes and pressures will provide a more accurate description of mass transfer characteristics of the CSTR for syngas fermentation. For large-scale syngas fermentation, the headspace pressure, gas flow rate, the power consumption, and reactor working volume are critical parameters for estimating the feasibility of fermentation process. The incorporation of these parameters into one model will help determine the operational parameters and meet the microbial kinetics requirement for syngas fermentation. No such models have been reported in the literature. In addition, backmixing of syngas components $\left(\mathrm{CO}\right.$ and $\left.\mathrm{H}_{2}\right)$ from the headspace into the fermentation medium can increase the gas substrate's retention time and improve gas conversion efficiency. The increase in the headspace pressure in the bioreactor at high agitation can increase the 
headspace gas backmixing. However, no reports were found on the effect of headspace gas backmixing on mass transfer for syngas fermentation reactors.

Typically, mass transfer characteristics of reactors are performed using a dynamic method with an air-water system due to simplicity of setup that only requires a dissolved oxygen (DO) probe [32]. The objectives of the present study were to experimentally investigate and model the $k_{\mathrm{L}} a$ for $\mathrm{O}_{2}$ in an air-water system at various gas flow rates, headspace pressures, agitation speeds, and working volumes using a 7-L CSTR. In addition, the effect of backmixing of headspace gas on $k_{\mathrm{L}} a$ was studied in non-sparged and sparged conditions. Moreover, a correlation of $k_{\mathrm{L}} a$ with power consumption and gas flow rate was developed. Finally, the $k_{\mathrm{L}} a$ for syngas components $\mathrm{CO}, \mathrm{CO}_{2}$ and $\mathrm{H}_{2}$ were estimated from $k_{\mathrm{L}} a$ for $\mathrm{O}_{2}$ based on the penetration or surface renewal theory $[33,34]$.

\section{Materials and Methods}

\subsection{CSTR Configuration and Operating Conditions}

A 7-L Bioflo 415 CSTR (New Brunswick Scientific Co., Edison, NJ, USA) was used, which is $14.6 \mathrm{~cm}$ in diameter and $41.9 \mathrm{~cm}$ in length (Figure 1). The configuration of the CSTR followed the suggestions by Bakker and Myers [35]. Four baffles, each $1.3 \mathrm{~cm}$ in width and $34.6 \mathrm{~cm}$ in length, were used to avoid liquid vortices. Two working volumes of 3 and $5.6 \mathrm{~L}$ of water at $43 \%$ and $80 \%$ of the total CSTR volume, respectively, were examined. The number of impellers mounted on the drive shaft was based on the ratio of gassed liquid level to the CSTR diameter [35]. Thus, two six-blade Rushton impellers were chosen with the $3 \mathrm{~L}$ working volume (Figure 1). For the $5.6 \mathrm{~L}$ working volume, three impellers were used consisting of two six-blade Rushton impellers and one curved three-blade marine impeller pumping downward (Figure 1). The downward marine impeller was selected to increase the gas retention time in the liquid and increase mass transfer area. The distance between all impellers was equal to the impeller diameter.
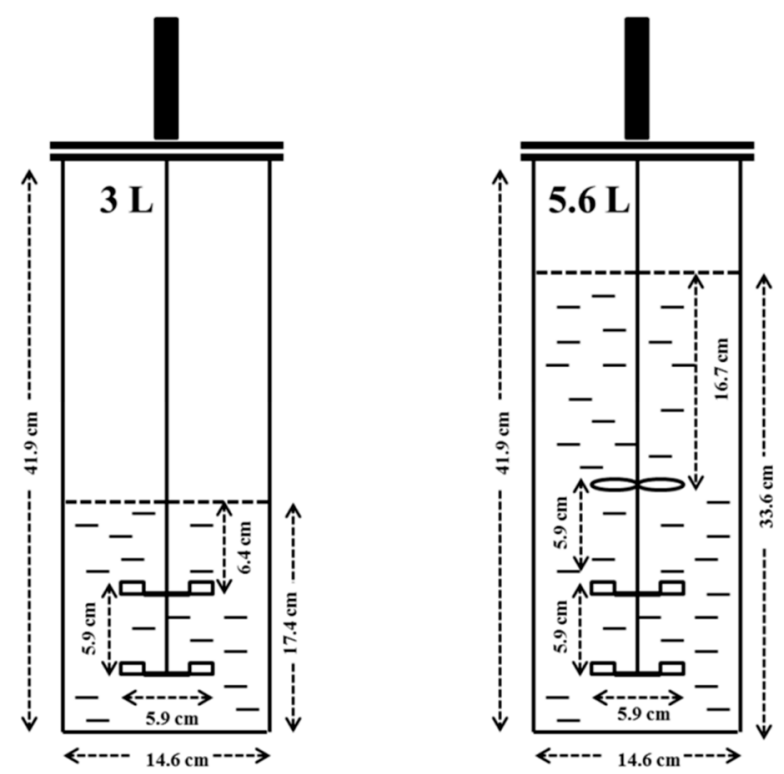

Figure 1. 7-L Bioflo 415 continuous stirred-tank reactor (CSTR) with the 3 and $5.6 \mathrm{~L}$ working volumes and impellers configuration.

The setup for the mass transfer study in the CSTR is shown in Figure 2. $\mathrm{N}_{2}$ or air (UHP/Zero grade, Stillwater Steel Co., Stillwater, OK, USA) was fed to the CSTR using a microsparger with 10-15 $\mu \mathrm{m}$ pore size (New Brunswick Scientific $\mathrm{Co}$.). The inlet $\mathrm{N}_{2}$ and air flow rates were controlled by two separate thermal mass flow controllers (MFC) (Burkert, Charlotte, NC, USA). Two $0.2 \mu \mathrm{m}$ pore size gas filters (New Brunswick Scientific Co.) were used in the inlet and outlet gas lines. The CSTR temperature was 
controlled at $37^{\circ} \mathrm{C}$ by a water heating jacket. A dissolved oxygen (DO) probe (InPro 6830, Mettler Toledo, Columbus, OH, USA) was used to measure \% DO saturation.

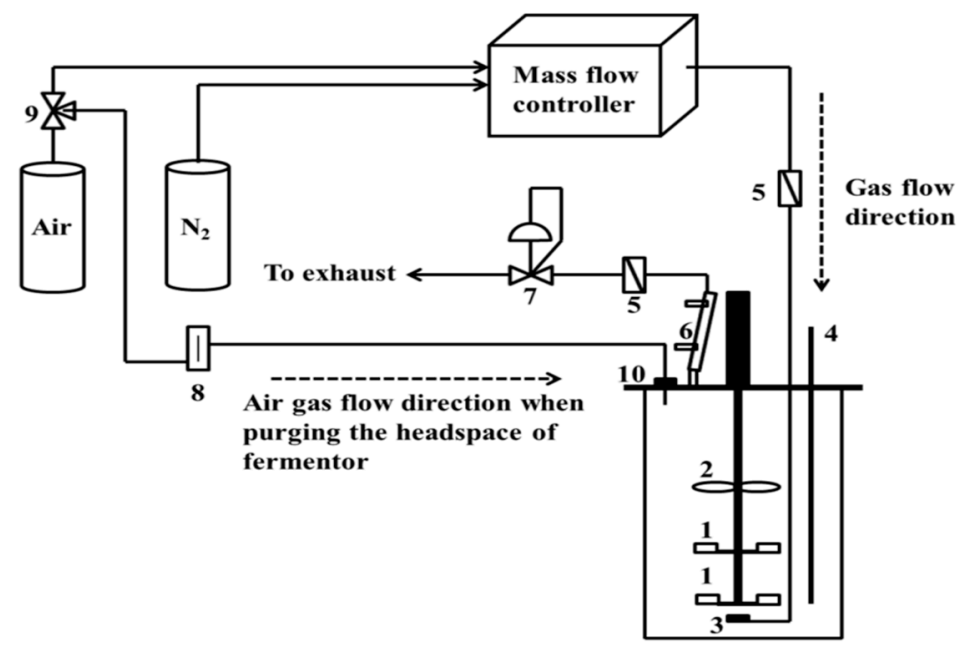

Figure 2. Bioflo 415 CSTR setup. (1) Rushton impellers, (2) marine impeller, (3) microsparger, (4) dissolved oxygen (DO) probe, (5) $0.2 \mu \mathrm{m}$ gas filters, (6) condenser, (7) backpressure regulator valve,

(8) rotameter, (9) two-way valve, and (10) headspace septum used with purging the headspace.

At the beginning of the experiment, the CSTR was first filled with deionized (DI) water to the required working volume ( 3 or $5.6 \mathrm{~L}$ ). The temperature was set at $37^{\circ} \mathrm{C}$ similar to syngas fermentation temperature. $\mathrm{N}_{2}$ was then sparged into the CSTR at $1000 \mathrm{sccm}$ (standard cubic centimeters per minute, $20^{\circ} \mathrm{C}$ and $101 \mathrm{kPa}$ ) to remove dissolved $\mathrm{O}_{2}$ from the DI water with the agitation speed set at $900 \mathrm{rpm}$ and headspace pressure of $101 \mathrm{kPa}$. The high $\mathrm{N}_{2}$ flow rate and agitation speed were used to shorten the $\mathrm{O}_{2}$ stripping time. Three headspace pressures (101, 150 and $240 \mathrm{kPa}$ ) were studied. When $\%$ DO in the DI water was less than $0.2 \%$, the headspace pressure was set at the desired pressure using a backpressure regulator. Then, $\mathrm{N}_{2}$ flow rate and agitation speed were adjusted to the desired conditions. When the headspace pressure was stable at the required set point, $\mathrm{N}_{2}$ flow was stopped and air flow was started at the desired flow rate. Three air flow rates of 90, 150, and $600 \mathrm{sccm}$ were tested. The agitation speeds examined were 150, 300, 450, 600, 750, and $900 \mathrm{rpm}$. The DO probe was calibrated at each tested pressure to $100 \%$ DO by saturating the DI water with sparging air at $1000 \mathrm{sccm}$ and $900 \mathrm{rpm}$. This eliminates the differences in the saturated \% DO at various headspace pressures. The $\%$ DO values did not exceed $100 \%$ saturation. The changes in the $\%$ DO in the DI water during aeration were recorded every $12 \mathrm{~s}$ by the Biocommand software (New Brunswick Scientific Co.) for the estimation of $k_{L} a$. When the \% DO in the water reached saturation, air flow was stopped. Experiments were performed in duplicates.

The effect of backmixing of gas from the headspace on $k_{L} a$ in a non-sparged and sparged CSTR was also examined. Backmixing experiments started by first calibrating the DO probe as mentioned earlier. The $\mathrm{O}_{2}$ in the DI water in the bioreactor was stripped by flowing $1000 \mathrm{sccm} \mathrm{N} \mathrm{N}_{2}$ at $101 \mathrm{kPa}$ until the $\%$ DO was near $0 \%$. Then, $\mathrm{N}_{2}$ flow and agitation were stopped. To replace the $\mathrm{N}_{2}$ in the CSTR headspace, the headspace was flushed with air at $1000 \mathrm{sccm}$ for $2 \mathrm{~min}$ at $101 \mathrm{kPa}$ by inserting a needle into the headplate septum as shown in Figure 2. After $2 \mathrm{~min}$, the pressure inside the CSTR was set at the test value of 101,150 or $240 \mathrm{kPa}$ by closing the backpressure regulator valve. Two agitation speeds (150 and $900 \mathrm{rpm}$ ) and two working volumes ( 3 and $5.6 \mathrm{~L}$ ) were examined in the non-sparged CSTR. Agitation was started immediately when the headspace pressure reached the required value. During the backmixing experiment with non-sparged CSTR, no air was sparged in the DI water and the CSTR exhaust was completely closed by the backpressure regulator valve (Figure 2). The backmixing experiment with the sparged CSTR was performed with the $3 \mathrm{~L}$ working volume and air sparged in 
the DI water at $600 \mathrm{sccm}$ and $900 \mathrm{rpm}$. The backpressure regulator valve was adjusted to keep the pressure in the headspace at the desired value.

\subsection{Calculations}

\subsubsection{Overall Volumetric Mass Transfer Coefficient}

The overall volumetric mass transfer coefficient, $k_{L} a$, was estimated by the following equation [15,32]:

$$
k_{\mathrm{L}} a=-\frac{\ln \left(1-\frac{\mathrm{C}_{\mathrm{L}}}{\mathrm{C}_{\mathrm{S}}}\right)}{t}
$$

where, $k_{\mathrm{L}}$ is liquid film mass transfer coefficient $\left(\mathrm{m} \mathrm{h}^{-1}\right), a$ is gas-liquid interfacial area per unit volume $\left(a=A / V_{L}\right)\left(\mathrm{m}^{-1}\right), A$ is the mass transfer area $\left(\mathrm{m}^{2}\right), V_{\mathrm{L}}$ is the liquid working volume in the CSTR $\left(\mathrm{m}^{3}\right)$, $k_{\mathrm{L}} a$ is overall volumetric mass transfer coefficient $\left(\mathrm{h}^{-1}\right), C_{\mathrm{S}}$ is the saturated $D O$ concentration in the liquid $\left(\mathrm{mol} \mathrm{m}^{-3}\right), C_{\mathrm{L}}$ is the $D O$ concentration in the bulk liquid $\left(\mathrm{mol} \mathrm{m}^{-3}\right)$, and $t$ is time $(\mathrm{h}) . C_{\mathrm{L}} / C_{\mathrm{S}}$ is replaced by $\% \mathrm{DO} / 100$ [15]. For calculating the $k_{\mathrm{L}} a$ in non-sparged CSTR at various pressures, $C_{\mathrm{S}}$ in Equation (1) was replaced by equilibrium saturated \% DO at the examined pressure. The $k_{\mathrm{L}} a$ value for $\mathrm{O}_{2}$ was estimated from the linear slope of $\ln \left(1-C_{\mathrm{L}} / C_{\mathrm{S}}\right)$ versus $t$ when $\% \mathrm{DO}$ was between $20 \%$ and $80 \%$ of saturation level.

\subsubsection{Volumetric Flow Rate at Various Headspace Pressures}

The molar and volumetric air flow rates at various pressures and $37^{\circ} \mathrm{C}$ were calculated using Equations (2) to (5) that included estimation of the pressure in the headspace and water hydraulic head above the microsparger in the CSTR [36]:

$$
\begin{gathered}
n_{\mathrm{a}}=\frac{\rho_{\mathrm{a}} \cdot V_{\mathrm{NIST}}}{M_{\mathrm{a}}} \\
P_{\mathrm{HP}}=\rho_{w} \cdot g \cdot h \\
P_{\text {total }}=P_{\mathrm{HS}}+P_{\mathrm{HP}} \\
Q_{\mathrm{g}}=\frac{n_{\mathrm{a}} \cdot R \cdot T_{310 \mathrm{~K}}}{P_{\text {total }}}
\end{gathered}
$$

where, $\rho_{\mathrm{a}}$ is air density at $20{ }^{\circ} \mathrm{C}\left(\mathrm{kg} \mathrm{m}^{-3}\right), M_{\mathrm{a}}$ is air molecular weight $\left(\mathrm{g} \mathrm{mol}^{-1}\right), V_{\mathrm{NIST}}$ is air flow rate $\left(\mathrm{m}^{3} \mathrm{~min}^{-1}\right)$ at standard National Institute of Science and Technology (NIST) conditions $\left(20^{\circ} \mathrm{C}\right.$, $101.3 \mathrm{kPa}$ ) set using the thermal mass flow controller (MFC), $n_{\mathrm{a}}$ is air molar flow rate from MFC $\left(\mathrm{mol} \mathrm{min}^{-1}\right), P_{\mathrm{HP}}$ is the hydraulic pressure above the microsparger $(\mathrm{kPa}), \rho_{\mathrm{w}}$ is water density $\left(\mathrm{kg} \mathrm{m}^{-3}\right)$, $g$ is gravitational acceleration $\left(\mathrm{m} \mathrm{s}^{-2}\right), h$ is the distance between the microsparger and liquid surface $(\mathrm{m}), P_{\mathrm{HS}}$ is the headspace pressure $(\mathrm{kPa}), P_{\text {total }}$ is the total pressure in the CSTR $(\mathrm{kPa}), Q_{\mathrm{g}}$ is the air volumetric flow rate $\left(\mathrm{mL} \mathrm{min}^{-1}\right), R$ is the ideal gas constant $\left(\mathrm{L} \mathrm{kPa} \mathrm{mol}^{-1} \mathrm{~K}^{-1}\right), T_{310 \mathrm{~K}}$ is the temperature used (310 K).

\subsubsection{Power Consumption}

The impellers used were two six-blade Rushton impellers for the $3 \mathrm{~L}$ working volume, and one marine impeller plus two six-blade Rushton impellers for the $5.6 \mathrm{~L}$ working volume. The marine impeller was estimated to have a power number at $40 \%$ of a single Rushton impeller [34]. The power number $\left(\mathrm{N}_{\mathrm{p}}\right)$ of a single six-blade Rushton impeller was reported to be 5.5 [35]. Thus, the calculated power number for the marine impeller of 2.2 was chosen. The power consumption of all impellers above a microsparger was calculated using Equations (6) to (10) as suggested [35]

$$
N_{\mathrm{A}}=\frac{Q_{\mathrm{g}}}{N \cdot D^{3}}
$$




$$
\begin{gathered}
N_{\mathrm{Fr}}=\frac{N^{2} \cdot D}{g} \\
P_{\mathrm{u}}=N_{p} \cdot \rho_{w} \cdot N^{3} \cdot D^{5} \\
P_{g, \text { lower }}=P_{\mathrm{u}} \cdot\left[1-(B-A \cdot \mu) \cdot N_{\mathrm{Fr}}^{E} \cdot \tanh \left(C \cdot N_{A}\right)\right] \\
P_{g, \text { upper }}=P_{\mathrm{u}} \cdot\left[1-\left(A+B \cdot N_{\mathrm{Fr}}\right) \cdot N_{\mathrm{A}}^{\mathrm{C}}+0.04 \mathrm{~N}_{\mathrm{Fr}}\right]
\end{gathered}
$$

where $N_{\mathrm{A}}$ is aeration number (dimensionless), $N_{\mathrm{Fr}}$ is Froude number (dimensionless), $Q_{\mathrm{g}}$ is the air volumetric flow rate $\left(\mathrm{mL} \mathrm{min}{ }^{-1}\right), g$ is gravity acceleration $\left(\mathrm{m} \cdot \mathrm{s}^{-2}\right), P_{\mathrm{u}}$ is the ungassed power consumption of a single impeller $(\mathrm{W}), N_{\mathrm{p}}$ is power number of a single Rushton impeller or marine impeller (dimensionless), $N$ is the impeller rotational speed $\left(\mathrm{s}^{-1}\right), D$ is the diameter of impeller $(\mathrm{m})$, $P_{\mathrm{g}, \text { lower }}$ is gassed power consumption of the single impeller mounted directly above the microsparger

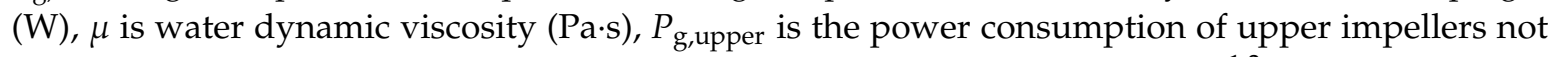
mounted directly above the gas sparger $(\mathrm{W}), A=5.3 \exp [-5.4(D / T)] ; B=0.47(D / T)^{1.3} ; C=0.64-1.1(D / T)$; $E=0.25$. $D$ is the impeller diameter $(\mathrm{m})$ and $T$ is the tank diameter $(\mathrm{m})$.

For the second Rushton impeller and marine impeller above the microsparger, the power consumption was calculated from Equation (10) [35]. The total power consumption under gassed condition, $P_{\mathrm{g}}$, is the additive power consumption from all impellers mounted on the shaft. For the $3 \mathrm{~L}$ working volume, $P_{\mathrm{g}}$ equals to the power consumption of one Rushton impeller directly above the microsparger calculated using Equation (9) plus the power consumption of the second Rushton impeller calculated using Equation (10). However, for the 5.6 L working volume, the total power consumption, $P_{\mathrm{g}}$, equals the power consumed by one Rushton impeller directly above the microsparger calculated using Equation (9) plus the power consumed by the second Rushton and third marine impellers calculated using Equation (10).

\subsubsection{Mass Transfer Model of a 7-L CSTR}

There are many reports in literature that described various correlations of the volumetric mass transfer coefficient, $k_{L} a$, at different operating parameters. However, the most used correlation for $k_{L} a$ is expressed in terms of power input per unit volume and superficial gas velocity [32,35,37,38]. The overall volumetric mass transfer coefficient typically follows the model below [35]:

$$
k_{\mathrm{L}} a=\mathrm{c} \cdot\left(\frac{P_{\mathrm{g}}}{V_{\mathrm{L}}}\right)^{\alpha} \cdot v_{\mathrm{g}}^{\beta}
$$

where $P_{\mathrm{g}}$ is the total impeller power consumption under gassed condition (W), $\alpha, \beta$ and $c$ are model parameters, $V_{\mathrm{L}}$ is the liquid working volume $\left(\mathrm{m}^{3}\right), v_{\mathrm{g}}$ is superficial gas velocity $\left(\mathrm{m} \mathrm{s}^{-1}\right)$. The model parameters $\alpha, \beta$ and $c$ in Equation (11) were estimated based on the volumetric flow rates at $37^{\circ} \mathrm{C}$, agitation speeds, and working volumes used in the present study. The least square approach and SOLVER function in EXCEL (Microsoft, Redmond, WA, USA) were used to estimate the model parameters $\alpha, \beta$ and $c$.

The $k_{L} a$ for $\mathrm{CO}, \mathrm{CO}_{2}$ and $\mathrm{H}_{2}$, were calculated from the measured $k_{L} a$ for $\mathrm{O}_{2}$ using the penetration or surface renewal theory based on their diffusivities in the fermentation broth. The $k_{L} a$ for gas species $i$ can be calculated from $k_{L} a$ for gas species $j$, using the following equation [33,34]:

$$
\frac{\left(k_{\mathrm{L}} a\right)_{\mathrm{i}}}{\left(k_{\mathrm{L}} a\right)_{\mathrm{j}}}=\left(\frac{D_{\mathrm{i}}}{D_{\mathrm{j}}}\right)^{1 / 2}
$$

where $D_{\mathrm{i}}$ and $D_{\mathrm{j}}$ are the diffusivities of gas species $i$ and $j\left(\mathrm{O}_{2}\right)$. In water, the diffusivities of $\mathrm{CO}, \mathrm{CO}_{2}$ and $\mathrm{H}_{2}$ were $107 \%, 90 \%$, and $212 \%$, respectively, of the $\mathrm{O}_{2}$ diffusivity at $37{ }^{\circ} \mathrm{C}$ [15]. Thus, the ratios of $\left(k_{\mathrm{L}} a\right)_{\mathrm{i}} /\left(k_{\mathrm{L}} a\right)_{\mathrm{O} 2}$ for $\mathrm{CO}, \mathrm{CO}_{2}$ and $\mathrm{H}_{2}$ based on their diffusivities are $1.03,0.95$ and 1.46 , respectively. 


\subsubsection{Statistical Analysis}

T-TEST procedure was performed using SAS Release 9.3 (Cary, NC, USA) to determine the statistical differences in the $k_{\mathrm{L}} a$ for $\mathrm{O}_{2}$ between when the headspace was flushed with air for 2 and $12 \mathrm{~min}$ in the non-sparged CSTR during the backmixing experiment at $95 \%$ confidence level. Also, the statistical differences of the $k_{\mathrm{L}} a$ for $\mathrm{O}_{2}$ in the backmixing study in the sparged CSTR with and without air flushing of the headspace were also determined by T-TEST procedure using SAS.

\section{Results and Discussion}

\subsection{Effect of Agitation Speed, Pressure and Gas Flow Rate on $k_{L} a$}

The effects of agitation speed, headspace pressure, and gas flow rate on the $k_{\mathrm{L}} a$ for $\mathrm{O}_{2}$ with the $3 \mathrm{~L}$ and 5.6 L working volumes in the air-water system are shown in Figure 3. The $k_{\mathrm{L}} a$ for $\mathrm{O}_{2}$ increased as agitation speed increased at fixed air flow rate, headspace pressure and working volume. Also, the mass transfer of $\mathrm{O}_{2}$ into the DI water was improved with increasing air flow rate. The highest measured $k_{\mathrm{L}} a$ for $\mathrm{O}_{2}$ was $116.2 \mathrm{~h}^{-1}$ at $600 \mathrm{sccm}, 900 \mathrm{rpm}$ and $101 \mathrm{kPa}$ with $3 \mathrm{~L}$ working volume (Figure 3). The measured $k_{\mathrm{L}} a$ values for $\mathrm{O}_{2}$ in $3 \mathrm{~L}$ working volume were generally $6 \%$ to $50 \%$ higher than with $5.6 \mathrm{~L}$ working volume at similar standard air flow rates, headspace pressures and all agitation speeds except at $900 \mathrm{rpm}$. At $900 \mathrm{rpm}$, the measured $k_{\mathrm{L}} a$ for $\mathrm{O}_{2}$ was generally $10 \%$ to $50 \%$ lower in the $3 \mathrm{~L}$ working volume than in the $5.6 \mathrm{~L}$ working volume at headspace pressures of 150 and $240 \mathrm{kPa}$ and flow rates 90 and $150 \mathrm{sccm}$. The decrease in the measured $k_{\mathrm{L}} a$ for $\mathrm{O}_{2}$ at these conditions was due to the backmixing of $\mathrm{N}_{2}$ and $\mathrm{O}_{2}$ depleted air from the headspace into the water.

As mentioned earlier, one of the challenges of syngas fermentation process is the mass transfer limitation due to low solubility of $\mathrm{CO}$ and $\mathrm{H}_{2}$ in the fermentation medium. Mass transfer can be increased by increasing the agitation speed and gas flow rate. In addition, the increase in headspace pressure improves molar mass transfer by increasing the driving force. Thus, it is important to determine the effect of headspace pressure on $k_{\mathrm{L}} a$ in sparged and non-sparged CSTRs to guide in reactor operation. The $k_{\mathrm{L}} a$ for $\mathrm{O}_{2}$ was the highest at the lowest headspace pressure of $101 \mathrm{kPa}$ compared to 150 and $240 \mathrm{kPa}$ at the same agitation speed, working volume and standard air flow rate in sccm. This decrease in $k_{\mathrm{L}} a$ is caused by lower volumetric gas flow at higher pressure. Estimated air flow rates at $37^{\circ} \mathrm{C}$ and headspace pressures of 150 and $240 \mathrm{kPa}$ were $32 \%$ and $57 \%$, respectively, lower than at $101 \mathrm{kPa}$. Thus, the actual volumetric gas flow rate that results from elevated headspace pressure should be considered in $k_{\mathrm{L}} a$ estimation. The hydraulic head above the microsparger should also be considered in the estimation of $k_{\mathrm{L}} a$ values in large fermentor. The decrease in volumetric air flow rate reduces the air superficial velocity, $\mathrm{vg}\left(\mathrm{m} \mathrm{s}^{-1}\right)$, as calculated from Equation (13), resulting in reduced $k_{\mathrm{L}} a$ in Equation (11).

$$
v_{\mathrm{g}}=\frac{Q_{\mathrm{g}}}{\pi \frac{T^{2}}{4}}
$$

The measured $k_{\mathrm{L}} a$ for $\mathrm{O}_{2}$ in the sparged CSTR with $3 \mathrm{~L}$ working volume decreased from $10 \%$ to $50 \%$ when the agitation speed increased from 750 to $900 \mathrm{rpm}$ and air flow rate was below $600 \mathrm{sccm}$ (Figure 3). However, the measured $k_{\mathrm{L}} a$ for $\mathrm{O}_{2}$ with the $3 \mathrm{~L}$ working volume increased when the agitation speed was increased from 750 to $900 \mathrm{rpm}$ at air flow rate of $600 \mathrm{sccm}$. The phenomenon of decreasing $k_{\mathrm{L}} a$ for $\mathrm{O}_{2}$ was not observed with the $5.6 \mathrm{~L}$ working volume even at $900 \mathrm{rpm}$. The decrease in measured $k_{\mathrm{L}} a$ in the $3 \mathrm{~L}$ working volume was attributed to severe backmixing of $\mathrm{N}_{2}$ in the headspace into water and $\mathrm{O}_{2}$ stripping from water, which increased the time for DO concentration reaching saturation values. There was 2.9 times more $\mathrm{N}_{2}$ initially present in the headspace in the sparged CSTR with the $3 \mathrm{~L}$ working volume compared to the $5.6 \mathrm{~L}$ working volume, which caused higher effect of backmixing on $k_{\mathrm{L}} a$ in the $3 \mathrm{~L}$ working volume. In addition, the amounts of $\mathrm{N}_{2}$ in the headspace at 150 and $250 \mathrm{kPa}$ were 1.5 times and 2.4 times, respectively, higher than at $101 \mathrm{kPa}$. The measured $k_{\mathrm{L}} a$ for $\mathrm{O}_{2}$ at air flow rate of $600 \mathrm{sccm}, 900 \mathrm{rpm}$ and $101 \mathrm{kPa}$ in the $3 \mathrm{~L}$ working volume increased from the 
$k_{\mathrm{L}} a$ measurement at $750 \mathrm{rpm}$ because the high air flow rate increased the $\mathrm{O}_{2}$ content in the headspace over four times faster than at 90 and $150 \mathrm{sccm}$. The measured $k_{\mathrm{L}} a$ for $\mathrm{O}_{2}$ remained almost constant at $600 \mathrm{sccm}$ with the headspace pressures of 150 and $240 \mathrm{kPa}$ when the agitation speed was increased from 750 to $900 \mathrm{rpm}$ with the $3 \mathrm{~L}$ working volume (Figure 3). This was due to lower volumetric air flow rates at 150 and $240 \mathrm{kPa}$, which could not flush $\mathrm{N}_{2}$ from headspace as fast as at $101 \mathrm{kPa}$.
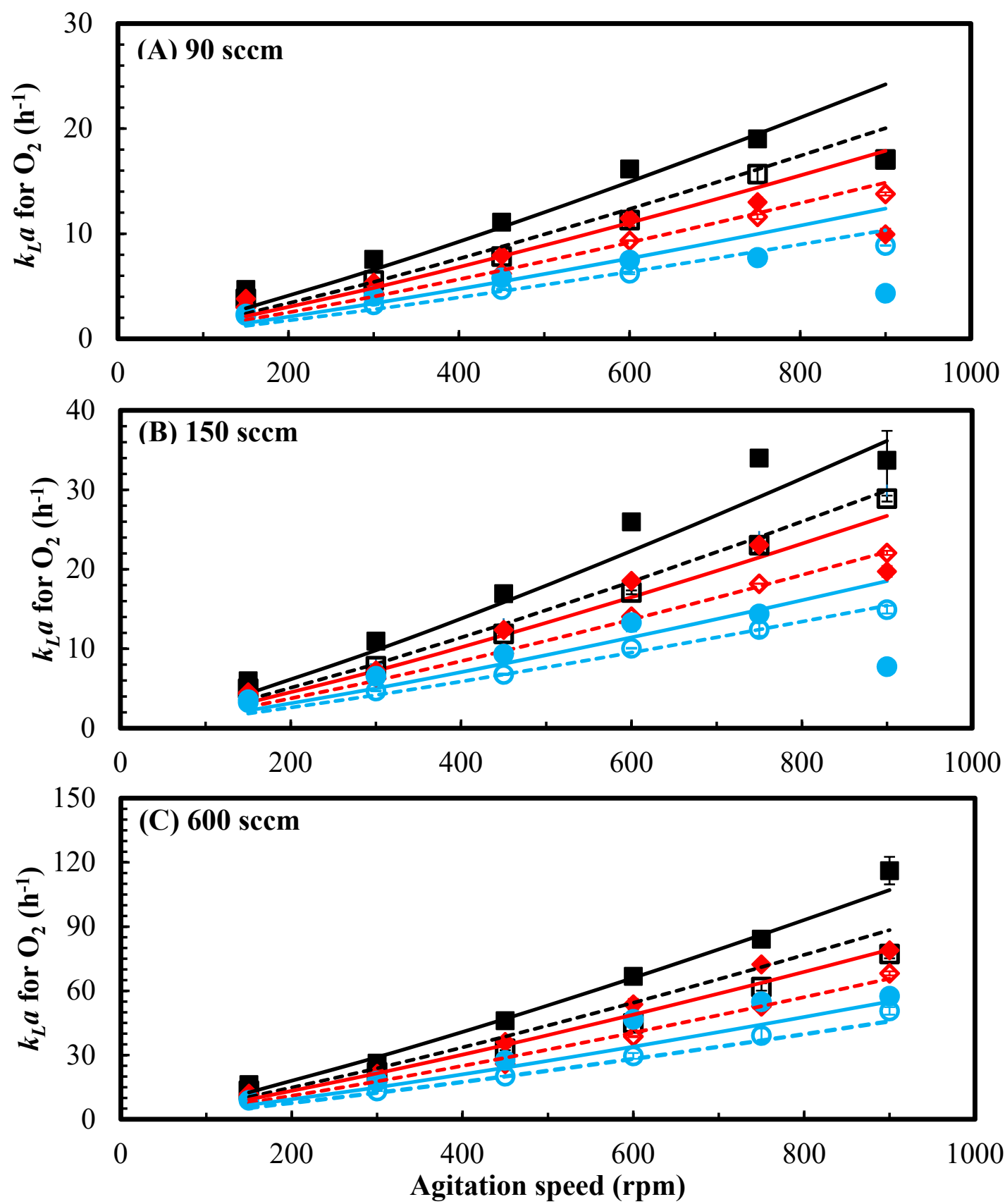

Figure 3. $k_{L} a$ for $\mathrm{O}_{2}$ in air water system at standard flow rates in standard cubic centimeters per minute, sccm, (A) $90 \mathrm{sccm}$, (B) $150 \mathrm{sccm}$ and (C) $600 \mathrm{sccm}$ and headspace pressures of $101 \mathrm{kPa}(\mathbf{\square})$, $150 \mathrm{kPa}(\bullet)$ and $240 \mathrm{kPa}(\bullet)$ in $3 \mathrm{~L}$ (experimental data in solid symbols, model predictions in solid lines) and 5.6 L (experimental data in open symbols, model predictions in dash lines) working volumes. Error bars not visible are smaller than the symbols. 


\subsection{Effect of Headspace Backmixing on $k_{L} a$}

The effect of backmixing from the headspace containing air on the $k_{\mathrm{L}} a$ for $\mathrm{O}_{2}$ in non-sparged CSTR and $3 \mathrm{~L}$ and $5.6 \mathrm{~L}$ working volumes was evaluated at agitation speeds of 150 and $900 \mathrm{rpm}$ and headspace pressures of 101, 150 and $240 \mathrm{kPa}$ (Table 1). In this set of experiments, the headspace was purged with air at $1000 \mathrm{sccm}$ for $2 \mathrm{~min}$ and pressure was set at the desired value. During the test at each condition, the inlet and outlet CSTR gas lines were completely closed. Results showed that the effect of backmixing of air from the headspace on the $k_{\mathrm{L}} a$ for $\mathrm{O}_{2}$ in the $5.6 \mathrm{~L}$ working volume was negligible compared to $3 \mathrm{~L}$ working volume (Table 1 ). For the CSTR with $3 \mathrm{~L}$ working volume at $150 \mathrm{rpm}$ and headspace pressures between 101 and $240 \mathrm{kPa}$, the backmixing of air from the headspace was low, resulting in $k_{\mathrm{L}} a$ values for $\mathrm{O}_{2}$ below $1.3 \mathrm{~h}^{-1}$. However, the $k_{\mathrm{L}} a$ for $\mathrm{O}_{2}$ increased from $0.7 \mathrm{~h}^{-1}$ to $67.3 \mathrm{~h}^{-1}$ due to backmixing of air from the headspace when the agitation speed was increased from $150 \mathrm{rpm}$ to $900 \mathrm{rpm}$ at $101 \mathrm{kPa}$. Moreover, the $k_{\mathrm{L}} a$ for $\mathrm{O}_{2}$ in the non-sparged CSTR at $900 \mathrm{rpm}$ increased by $77 \%$ with the increase in the air pressure in the headspace from 101 to $240 \mathrm{kPa}$ in the $3 \mathrm{~L}$ working volume. This explains the decrease in the $k_{\mathrm{L}} a$ for $\mathrm{O}_{2}$ when air was sparged into the water with initial $\mathrm{N}_{2}$ headspace was due to backmixing of $\mathrm{N}_{2}$ from the headspace at $900 \mathrm{rpm}$ with pressures of 150 and $240 \mathrm{kPa}$ at air flow rates of 90 and $150 \mathrm{sccm}$ (Figure 3).

Table 1. Effect of headspace pressure and backmixing at 150 and $900 \mathrm{rpm}$ on $k_{\mathrm{L}}$ a for $\mathrm{O}_{2}$ in a non-sparged CSTR with 3 and $5.6 \mathrm{~L}$ working volumes.

\begin{tabular}{|c|c|c|c|c|c|c|}
\hline Parameters & & & & & & \\
\hline Headspace pressure $(\mathrm{kPa})$ & 101 & 101 & 150 & 150 & 240 & 240 \\
\hline Agitation speed (rpm) & 150 & 900 & 150 & 900 & 150 & 900 \\
\hline$k_{\mathrm{L}} a$ for $\mathrm{O}_{2}\left(\mathrm{~h}^{-1}\right)^{\mathrm{a}}$ & $0.7 \pm 0.0$ & $67.3 \pm 1.0^{\dagger}$ & $0.8 \pm 0.0$ & $92.0 \pm 3.5^{\dagger}$ & $1.3 \pm 0.4$ & $119.3 \pm 2.1^{\dagger}$ \\
\hline$k_{\mathrm{L}} a$ for $\mathrm{O}_{2}\left(\mathrm{~h}^{-1}\right)^{\mathrm{b}}$ & $-\ddagger$ & $67.0 \pm 0.2^{\dagger}$ & - & $88.2 \pm 0.3^{\dagger}$ & - & $122.3 \pm 1.4^{+}$ \\
\hline$k_{\mathrm{L}} a$ for $\mathrm{O}_{2}\left(\mathrm{~h}^{-1}\right)^{\mathrm{c}}$ & $0.2 \pm 0.0$ & $1.5 \pm 0.0$ & $0.2 \pm 0.0$ & $1.8 \pm 0.0$ & $0.3 \pm 0.0$ & $1.8 \pm 0.0$ \\
\hline
\end{tabular}

In addition to the higher headspace volume with the $3 \mathrm{~L}$ working volume, the high $k_{L} a$ from backmixing at $900 \mathrm{rpm}$ was attributed to the impeller arrangement in the CSTR. The distance from the top impeller to the liquid surface was $6.4 \mathrm{~cm}$ in the $3 \mathrm{~L}$ working volume (Figure 1). However, there was $16.7 \mathrm{~cm}$ between the top impeller and the liquid surface in the $5.6 \mathrm{~L}$ working volume. No vortex was observed in the $5.6 \mathrm{~L}$ working volume at $900 \mathrm{rpm}$. However, a vortex formed between the water surface and the top impeller in the $3 \mathrm{~L}$ working volume, drawing gas from the headspace to circulate in the liquid.

To determine the effect of the headspace flushing time on backmixing and estimation of $k_{L} a$ for $\mathrm{O}_{2}$, the headspace in the CSTR with $3 \mathrm{~L}$ working volume was flushed with air for 2 and $12 \mathrm{~min}$ at $1000 \mathrm{sccm}$. Flushing the CSTR headspace for $2 \mathrm{~min}$ at $1000 \mathrm{sccm}$ represented about $50 \%$ of the headspace volume with the $3 \mathrm{~L}$ working volume. However, using $\mathrm{O}_{2}$ saturation when each run reached equilibrium as \% DO for Cs in Eq. 1 corrected for the lower initial concentration of $\mathrm{O}_{2}$ in the headspace that resulted from low purging time. In addition, the results showed that there was no statistical difference $(p>0.05)$ between the headspace flushing times (Table 1). Thus, 2 min was sufficient to flush the headspace with air to evaluate the backmixing effect on the $k_{L} a$ for $\mathrm{O}_{2}$.

The estimation of $k_{L} a$ from Equation (1) assumes a constant $\mathrm{O}_{2}$ concentration at the gas/liquid interface, Cs. However, $\mathrm{O}_{2}$ transferred into the water is removed from the headspace gas lowering the $\mathrm{O}_{2}$ concentration at the interface. The change of $\mathrm{O}_{2}$ concentration in the headspace was estimated by the $\mathrm{O}_{2}$ mass balance and the equilibrium $\mathrm{O}_{2}$ saturation (\% DO) to be $2 \%$ and $9 \%$ for the 3 and $5.6 \mathrm{~L}$ working volumes, respectively. The mass transfer driving force for $\mathrm{O}_{2}$ transfer was estimated by the logarithmic mean of the initial difference of partial pressure in the gas and $0 \mathrm{kPa}$ in the water, and a low terminal partial pressure difference of $0.2 \mathrm{kPa}$ between the gas and the near equilibrium saturation 
of the water. This estimation shows the average driving force increases with pressure. This suggests that the increase in observed $k_{L} a$ for $\mathrm{O}_{2}$ in the non-sparged CSTR due to backmixing with increased pressure resulted from increased driving force.

The backmixing effect with the $5.6 \mathrm{~L}$ working volume was less than $2 \mathrm{~h}^{-1}$. Therefore, the subsequent experiments on effect of backmixing were done with the $3 \mathrm{~L}$ working volume. In this set of experiments, the headspace was flushed with air before air was sparged in water through the CSTR inlet sparger to evaluate if the backmixing of air affects the $k_{L} a$ for $\mathrm{O}_{2}$ in the $3 \mathrm{~L}$ working volume at $600 \mathrm{sccm}$ and $900 \mathrm{rpm}$ and various headspace pressures.

The $k_{L} a$ for $\mathrm{O}_{2}$ increased between $20 \%$ and $48 \%$ when the headspace was flushed with air before flowing air into the CSTR compared to no air flushing (i.e., only $\mathrm{N}_{2}$ in the headspace) (Table 2). The $k_{\mathrm{L}} a$ for $\mathrm{O}_{2}$ were $32 \%$ and $50 \%$ lower at $150 \mathrm{kPa}$ and $240 \mathrm{kPa}$, respectively, compared to $101 \mathrm{kPa}$ when the headspace was not initially flushed with air (Table 2). However, when the headspace was flushed with air, the $k_{\mathrm{L}} a$ values for $\mathrm{O}_{2}$ were $16 \%$ and $41 \%$ lower at $150 \mathrm{kPa}$ and $240 \mathrm{kPa}$, respectively, than at $101 \mathrm{kPa}$. This was due to $32 \%$ and $57 \%$ lower superficial gas velocities at 150 and $240 \mathrm{kPa}$, respectively, compared to $101 \mathrm{kPa}$. In addition, the differences in $k_{\mathrm{L}} a$ values for $\mathrm{O}_{2}$ were lower when the headspace was flushed with air at 150 and $240 \mathrm{kPa}$ compared to $101 \mathrm{kPa}$ since higher initial $\mathrm{O}_{2}$ content in the headspace added to the rate of $\mathrm{O}_{2}$ saturation compared to stripping of $\mathrm{O}_{2}$ by the $\mathrm{N}_{2}$ headspace.

Table 2. Effect of headspace pressure and backmixing on $k_{L} a$ for $\mathrm{O}_{2}$ in a sparged CSTR with $3 \mathrm{~L}$ working volume at standard air flow rate of $600 \mathrm{sccm}$ and $900 \mathrm{rpm}$.

\begin{tabular}{|c|c|c|c|}
\hline Parameters & & & \\
\hline Headspace pressure $(\mathrm{kPa})^{\mathrm{a}}$ & 101 & 150 & 240 \\
\hline Volumetric flow rate at $37^{\circ} \mathrm{C}(\mathrm{mL} \mathrm{min}-1)$ & 628 & 428 & 270 \\
\hline$k_{L} a$ without flushing headspace with air $\left(\mathrm{h}^{-1}\right)$ & $116.2 \pm 6.4$ & $79.0 \pm 0.1^{\dagger}$ & $57.7 \pm 0.5^{\dagger}$ \\
\hline$k_{L} a$ with flushing headspace with aira $\left(\mathrm{h}^{-1}\right)$ & $139.8 \pm 5.4$ & $116.8 \pm 5.7^{\dagger}$ & $82.6 \pm 1.4^{+}$ \\
\hline$k_{L} a$ increase due to backmixing (\%) & 20.3 & 47.9 & 43.2 \\
\hline
\end{tabular}

Utilizing the backmixing effect can be useful in syngas fermentation. Under low syngas conversion, the unutilized gas in the headspace can be entrained back into the medium, thus improving mass transfer and conversion of syngas components such as $\mathrm{CO}$ and $\mathrm{H}_{2}$ into products. However, if conversion of $\mathrm{CO}$ and $\mathrm{H}_{2}$ was high, the inert gas such as $\mathrm{N}_{2}$ from the producer gas derived from biomass [39] in the headspace can reduce the $k_{\mathrm{L}} a$ for $\mathrm{CO}$ or $\mathrm{H}_{2}$ at high agitation speed due to backmixing. Thus, it would be beneficial to operate the syngas fermentation at low agitation speed, and high working volume to alleviate the backmixing effect when the syngas conversion efficiency is high. However, other factors such as gas flow rate, gas uptake rate, and agitation speed should be considered in evaluating the benefits of backmixing on syngas fermentation.

\subsection{Model Predictions of $k_{L}$ a for $\mathrm{O}_{2}$}

Equation (11) was used to predict the $k_{L} a$ for $\mathrm{O}_{2}$ at air flow rates (90, 150 and $600 \mathrm{sccm}$ ), various agitation speeds (150 to $900 \mathrm{rpm}$ ), working volumes (3 and $5.6 \mathrm{~L}$ ) and headspace pressures $(101,150$ and $240 \mathrm{kPa}$ ). Based on the experimental data, the air flow rates at standard condition in sccm were converted using Equations (2) to (5) into the corresponding volumetric flow rates in $\mathrm{mL} \mathrm{min}^{-1}$ at $37^{\circ} \mathrm{C}$ and the various hydraulic heads and headspace pressures used. The power consumption per unit volume $\left(P_{\mathrm{g}} / V_{\mathrm{L}}\right)$ and superficial velocity were calculated using Equations (6) to (10) and (13). Using the experimental data, the constants $\alpha, \beta$ and $c$ in Equation (11) were determined and the $k_{L} a$ for $\mathrm{O}_{2}$ can be estimated using Equation (14).

$$
\left(k_{\mathrm{L}} a\right)_{\mathrm{O}_{2}}=1080 \cdot\left(\frac{P_{\mathrm{g}}}{V_{\mathrm{L}}}\right)^{0.39} \cdot v_{\mathrm{g}}^{0.79}
$$


The parameters $\alpha$ and $\beta$ in Equation (11) were reported in the range of 0.3 to 0.7 and 0.0 to 1.0, respectively, and the variance of these parameters was due to measurement error and the configuration of stirred tank reactors $[11,40]$.

In the present study, the values of $\alpha$ and $\beta$ parameters of 0.39 and 0.79 , respectively, were within the previously reported range. As shown in Figure 3, there were less than $10 \%$ variation between the experimental data and model predictions of the $k_{\mathrm{L}} a$ for $\mathrm{O}_{2}$ in the CSTR with $5.6 \mathrm{~L}$ working volume. When agitation speeds were low, mainly 150 to $600 \mathrm{rpm}$ in $3 \mathrm{~L}$ working volume, less than $10 \%$ variation between the experimental and predicted $k_{L} a$ values for $\mathrm{O}_{2}$ were observed. However, there were $30 \%$ to $60 \%$ variation between the experimental and predicted $k_{L} a$ values for $\mathrm{O}_{2}$ in the $3 \mathrm{~L}$ working volume at low standard flow rate 90 and $150 \mathrm{sccm}$ and agitation speed above $750 \mathrm{rpm}$. This was due to the backmixing of $\mathrm{N}_{2}$ that lowered the observed $k_{L} a$ deviating from model predictions. The superficial gas velocity $v_{\mathrm{g}}$ in Equation (11) was determined using the volumetric flow rate at $37^{\circ} \mathrm{C}$ as shown in Equation (13). Higher headspace pressures for the same standard flow rate in sccm resulted in lower volumetric flow rates in $\mathrm{mL} \min ^{-1}$ at $37^{\circ} \mathrm{C}$ and lower $v_{\mathrm{g}}$ and $k_{L} a$. The model predictions of $k_{L} a$ for $\mathrm{O}_{2}$ were compared with the experimental results at various agitation speeds and volumetric flow rates (Figure 4). In addition, the model predictions of the $k_{L} a$ for $\mathrm{O}_{2}$ were plotted versus experimental data, which were mostly within $10 \%$ of variance (Figure 5). The $\mathrm{R}^{2}$ value for model predictions of the experimental data was 0.97 , indicating a very good fit.

The 3 and $5.6 \mathrm{~L}$ working volumes used were $43 \%$ and $80 \%$ of the total bioreactor volume $(7 \mathrm{~L}$ ), respectively. It is desired to operate the bioreactor at high working volume to increase the amount of products produced. However, factors such as power consumption and foam formation should be considered when selecting the working volume. The power per unit volume, $P_{\mathrm{g}} / V_{\mathrm{L}}$, was calculated using Equations (6) to (10). Increasing the agitation speed from 150 to $900 \mathrm{rpm}$ increased power consumption from 33 to $8181 \mathrm{~W} \mathrm{~m}^{-3}$ and from 21 to $5216 \mathrm{~W} \mathrm{~m}^{-3}$ in the $3 \mathrm{~L}$ and $5.6 \mathrm{~L}$ working volumes, respectively. The $P_{\mathrm{g}} / V_{\mathrm{L}}$ slightly decreased (no more than $8 \%$ ) when air flow rate was increased from 90 to $600 \mathrm{sccm}$ and headspace pressure was increased from 101 to $240 \mathrm{kPa}$. This showed that the increase in flow rate and headspace pressure within the tested ranges had small effects on $P_{\mathrm{g}} / V_{\mathrm{L}}$.

Although the predicted $k_{L} a$ for $\mathrm{O}_{2}$ in $3 \mathrm{~L}$ working volume was from $6 \%$ to $50 \%$ higher than in $5.6 \mathrm{~L}$ working volume at similar operating conditions, the $P_{\mathrm{g}} / V_{\mathrm{L}}$ consumed in $5.6 \mathrm{~L}$ working volume was about $37 \%$ lower than in $3 \mathrm{~L}$ working volume indicating the advantage of using higher working volumes in terms of power consumption. In addition, when high conversion efficiencies of $\mathrm{CO}, \mathrm{CO}_{2}$ and $\mathrm{H}_{2}$ in $3 \mathrm{~L}$ working volume were to be attained, the backmixing of $\mathrm{N}_{2}$ from producer gas [39] would diminish the advantage of using this working volume with higher $k_{L} a$ than the $5.6 \mathrm{~L}$ working volume.

\subsection{Model Predictions of $k_{\mathrm{L}}$ a for $\mathrm{CO}, \mathrm{CO}_{2}$ and $\mathrm{H}_{2}$}

Syngas fermentation is a strictly anaerobic fermentation process which excludes $\mathrm{O}_{2}$ in the process. It is more convenient to measure the $k_{L} a$ for $\mathrm{O}_{2}$ using an air-water system for the simplicity of the method and then predict the $k_{L} a$ for $\mathrm{CO}, \mathrm{CO}_{2}$ and $\mathrm{H}_{2}$. The $k_{L} a$ for $\mathrm{CO}, \mathrm{CO}_{2}$ and $\mathrm{H}_{2}$ were calculated from the model prediction of $k_{L} a$ for $\mathrm{O}_{2}$ (Equation (14)) based on the penetration or surface renewal theory $[33,34]$ as shown in Equations (15) to (17).

$$
\begin{aligned}
& \left(k_{\mathrm{L}} a\right)_{\mathrm{CO}}=1116 \cdot\left(\frac{P_{\mathrm{g}}}{V_{\mathrm{L}}}\right)^{0.39} \cdot v_{\mathrm{g}}^{0.79} \\
& \left(k_{\mathrm{L}} a\right)_{\mathrm{CO}_{2}}=1044 \cdot\left(\frac{P_{\mathrm{g}}}{V_{\mathrm{L}}}\right)^{0.39} \cdot v_{\mathrm{g}}^{0.79} \\
& \left(k_{\mathrm{L}} a\right)_{\mathrm{H}_{2}}=1584 \cdot\left(\frac{P_{\mathrm{g}}}{V_{\mathrm{L}}}\right)^{0.39} \cdot v_{\mathrm{g}}^{0.79}
\end{aligned}
$$


Based on Equations (15) to (17), the $k_{L} a$ for $\mathrm{CO}$ was $6 \%$ higher and $30 \%$ lower than the $k_{L} a$ for $\mathrm{CO}_{2}$ and $\mathrm{H}_{2}$, respectively, at all similar operating conditions. For syngas fermentation in a CSTR, the $k_{L} a$ for $\mathrm{CO}, \mathrm{CO}_{2}$ and $\mathrm{H}_{2}$ can be estimated if the bioreactor size, number and type of impellers, working volume, agitation speeds, headspace and hydraulic pressures and gas flow rates are known.
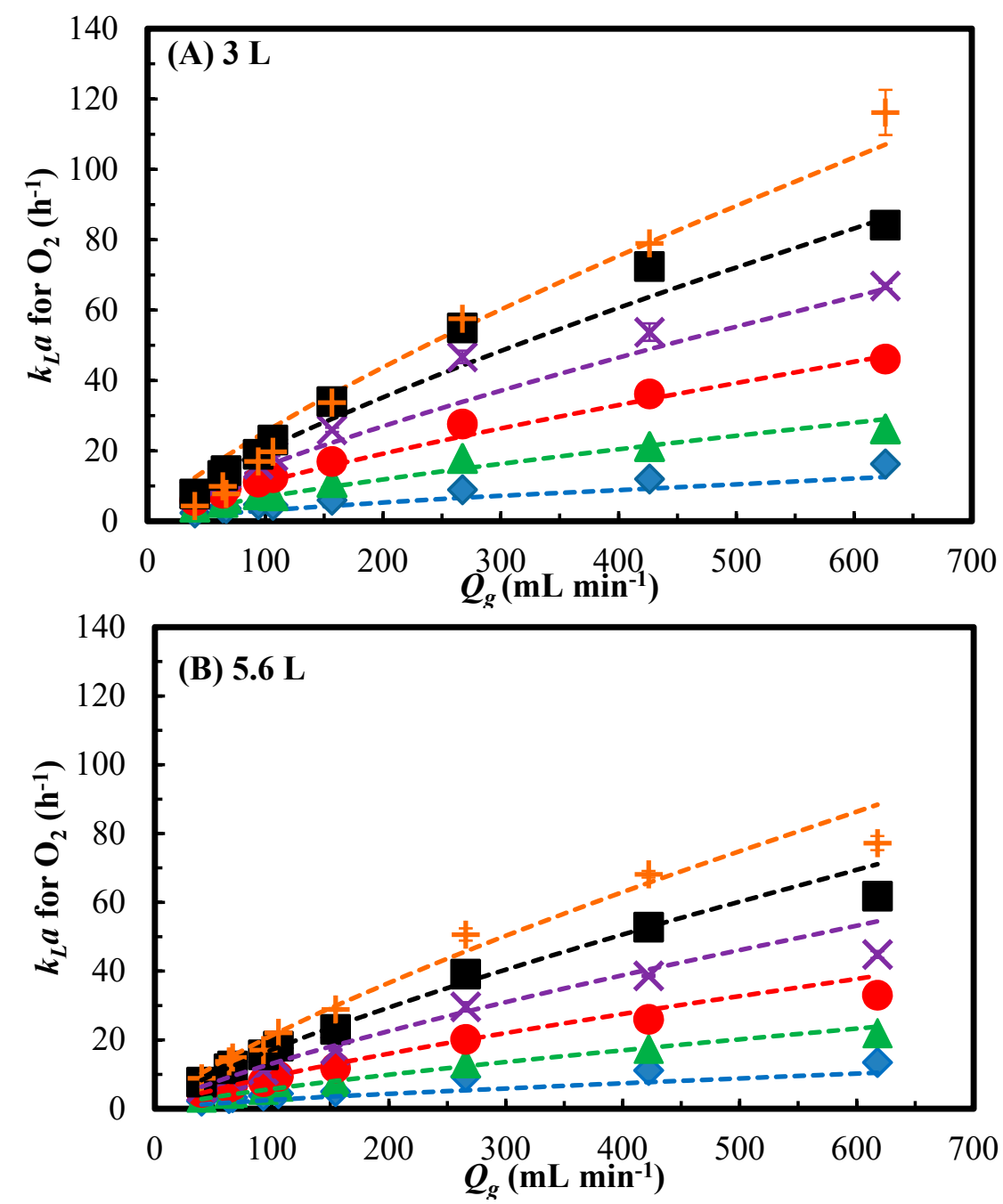

Figure 4. Experimental and predicted $k_{\mathrm{L}} a$ for $\mathrm{O}_{2}$ in (A) $3 \mathrm{~L}$ and (B) $5.6 \mathrm{~L}$ working volumes in the $7 \mathrm{~L}$ Bioflo 415 CSTR at volumetric flow rates between $40 \mathrm{~mL} \mathrm{~min}^{-1}$ to $630 \mathrm{~mL} \mathrm{~min}^{-1}$ and $37^{\circ} \mathrm{C}$ and various agitation speeds: $150 \mathrm{rpm}(\bullet), 300 \mathrm{rpm}(\boldsymbol{\Delta}), 450 \mathrm{rpm}(\bullet), 600 \mathrm{rpm}(\times), 750 \mathrm{rpm}(\boldsymbol{\bullet})$ and $900 \mathrm{rpm}(+)$; model prediction (dash lines). Error bars not visible are smaller than the symbols.

Syngas fermentation in CSTR requires high power input to obtain high $k_{L} a$. [11,15] Therefore, CSTR operating conditions should be carefully selected to reduce the power input to make the process more economically feasible. As shown in Figure 6, the predicted $k_{L} a$ for $\mathrm{O}_{2}$ increased with the increase in the $P_{\mathrm{g}} / V_{\mathrm{L}}$. The trends of $k_{\mathrm{L}} a$ for $\mathrm{O}_{2}$ were similar in 3 and $5.6 \mathrm{~L}$ working volumes at the same standard flow rate and headspace pressure. The $k_{L} a$ values for $\mathrm{O}_{2}$ increased by over four times when the flow rate was increased from 90 to $600 \mathrm{sccm}$ at the same headspace pressure and $P_{\mathrm{g}} / V_{\mathrm{L}}$. Therefore, higher $k_{L} a$ for $\mathrm{O}_{2}$ can be realized by increasing the air flow rate without increasing the $P_{\mathrm{g}} / V_{\mathrm{L}}$. However, while increasing gas flow rate during syngas fermentation increases $k_{L} a$, this can reduce syngas conversion efficiency when gas transfer rate exceeds the kinetic capacity of the cells. High cell concentrations are required to increase the gas conversion efficiency at high gas flow rates. Increased cell concentration in the fermentor was successfully demonstrated using membrane module for cell recycle [41,42]. Moreover, the increase in the headspace pressure from 101 to $240 \mathrm{kPa}$ decreased the $k_{L} a$ for $\mathrm{O}_{2}$ by $48 \%$ 
at similar $P_{\mathrm{g}} / V_{\mathrm{L}}$. This means that higher $P_{\mathrm{g}} / V_{\mathrm{L}}$ is required to achieve the same $k_{\mathrm{L}} a$ for $\mathrm{O}_{2}$ at higher pressure, offsetting the higher driving force gained at high pressure. The change of $k_{L} a$ for $\mathrm{O}_{2}$ as a function of $P_{\mathrm{g}} / V_{\mathrm{L}}$ would be similar to $k_{\mathrm{L}} a$ for $\mathrm{CO}, \mathrm{CO}_{2}$ and $\mathrm{H}_{2}$ during syngas fermentation. When operating syngas fermentation bioreactors, Equations (15) to (17) are useful to predict the mass transfer capacity for $\mathrm{CO}, \mathrm{CO}_{2}$ and $\mathrm{H}_{2}$ based on the uptake ability of the culture used, and therefore can guide in setting the operating conditions to minimize $P_{\mathrm{g}} / V_{\mathrm{L}}$ and maximize gas conversion efficiency.

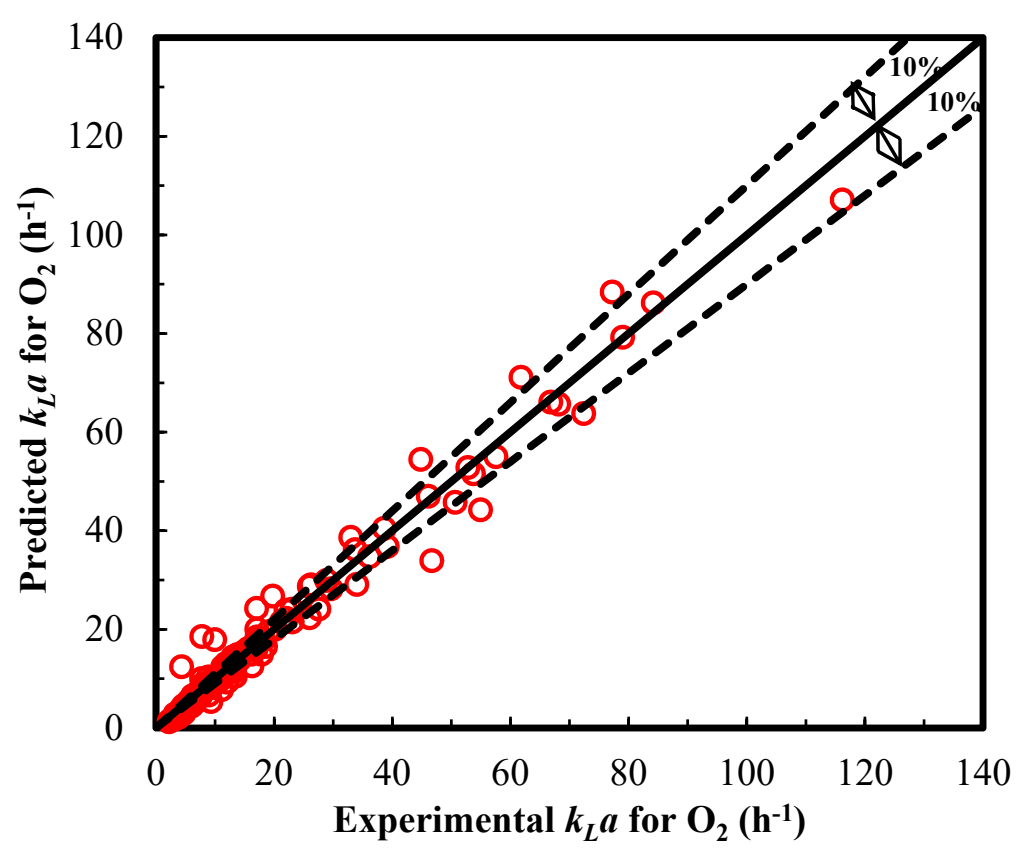

Figure 5. Predicted versus experimental $k_{L} a$ for $\mathrm{O}_{2}$ at volumetric flow rates between $40 \mathrm{~mL} \mathrm{~min}^{-1}$ to $630 \mathrm{~mL} \mathrm{~min}^{-1}$ and $37^{\circ} \mathrm{C}$, agitation speeds range from $150 \mathrm{rpm}$ to $900 \mathrm{rpm}$ in the $3 \mathrm{~L}$ and $5.6 \mathrm{~L}$ working volumes.

$k_{L} a$ values for different reactors using air and syngas components were reported by various research groups (Table 3). Based on Equation (12), $k_{L} a$ for $\mathrm{CO}$ is 1.03 the $k_{L} a$ for $\mathrm{O}_{2}$. However, it is difficult to compare $k_{L} a$ values based on the same gas accurately because of the different reactors and operating parameters used and unreported data about reactor volume, gas and liquid flow rates, pressure and agitation (Table 3). However, a comparison of the data from the literature showed that the $k_{L} a$ values of the HFR and TBR reactors were greatly higher than in various reported CSTRs [15,20,43,44]. HFR reactors showed remarkably high $k_{L} a$ values (about $1000 \mathrm{~h}^{-1}$ ), which depended on the type of the membrane, surface area to unit volume, gas flow rate and pressure [15,24,43]. An increase in the gas pressure in the HFR increased the $k_{L} a[20,43]$. However, an increase in the gas pressure in the CSTR decreased $k_{L} a$ due to lower volumetric gas flow rate at high pressure (Table 3). The $k_{L} a$ values reported for CSTRs in Table 3 were below $160 \mathrm{~h}^{-1}[18,45,46]$. However, the $k_{L} a$ values for the TBR, air-lift and MBR coupled with CSTR were 421,130 and $450 \mathrm{~h}^{-1}$, respectively $[15,16,47]$.

The present study showed that $k_{L} a$ values in the CSTR increased by increasing the gas flow rate and agitation speed (Figure 3). In addition, the $k_{L} a$ values in sparged CSTR increased with a decrease in the headspace pressure. However, the $k_{L} a$ values in non-sparged CSTR increased with an increase in the headspace pressure and agitation due to increased backmixing (Table 1). These results provide guidance in design, operation, and scale up of syngas fermentation reactors. 

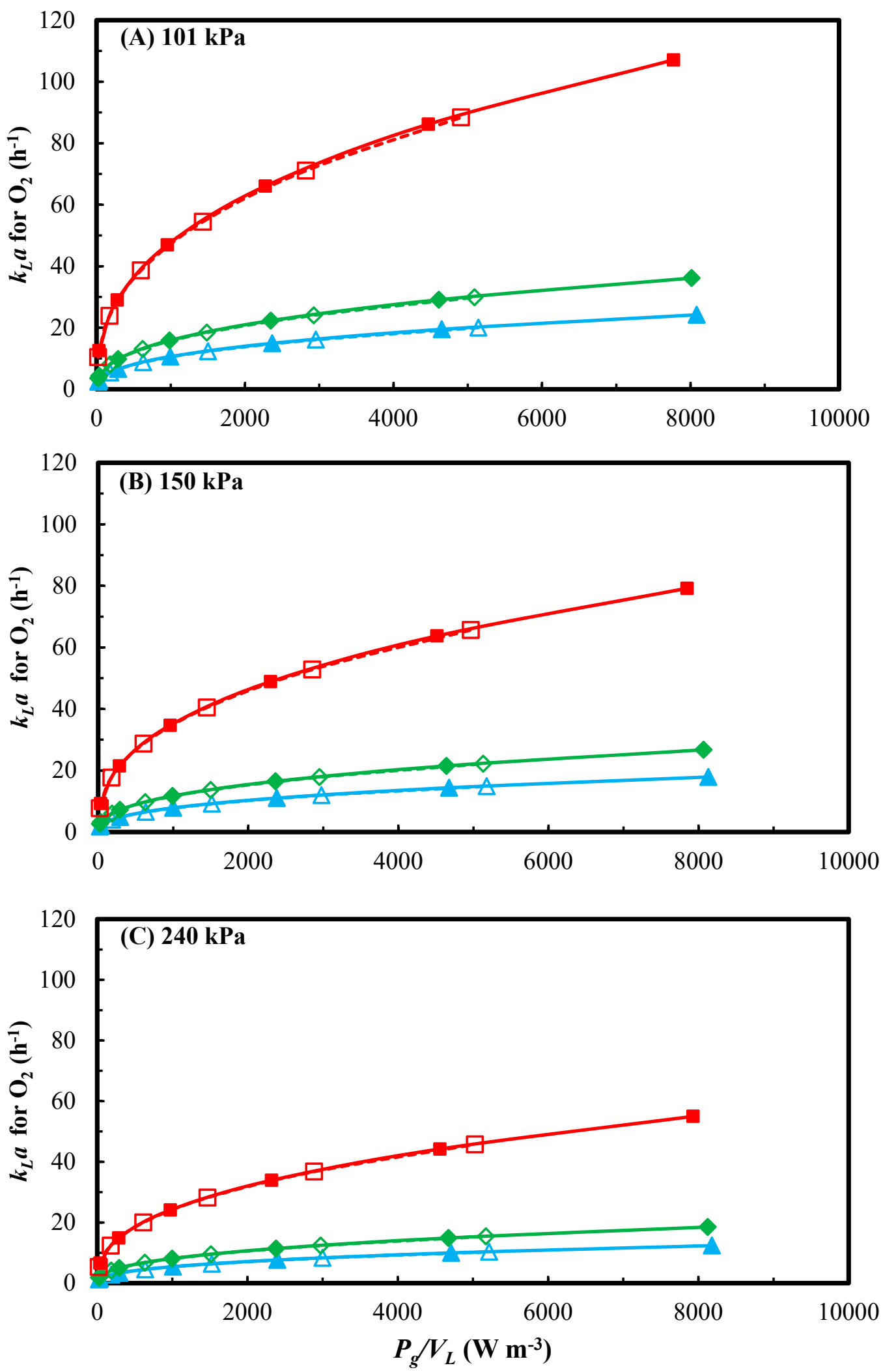

Figure 6. Profiles of predicted $k_{\mathrm{L}} a$ for $\mathrm{O}_{2}$ with $P_{\mathrm{g}} / V_{\mathrm{L}}$ at various headspace pressures (A) $101 \mathrm{kPa}$ (B) $150 \mathrm{kPa}(\mathbf{C}) 240 \mathrm{kPa}$ and $90 \mathrm{sccm}(\mathbf{\Delta}), 150 \mathrm{sccm}(\diamond)$ and $600 \mathrm{sccm}$ (匹) in $3 \mathrm{~L}$ working volume (solid symbol and solid line) and 5.6 L working volume (open symbol and dash line). 
Table 3. Mass transfer coefficient $k_{L} a$ in different bioreactors and operating parameters.

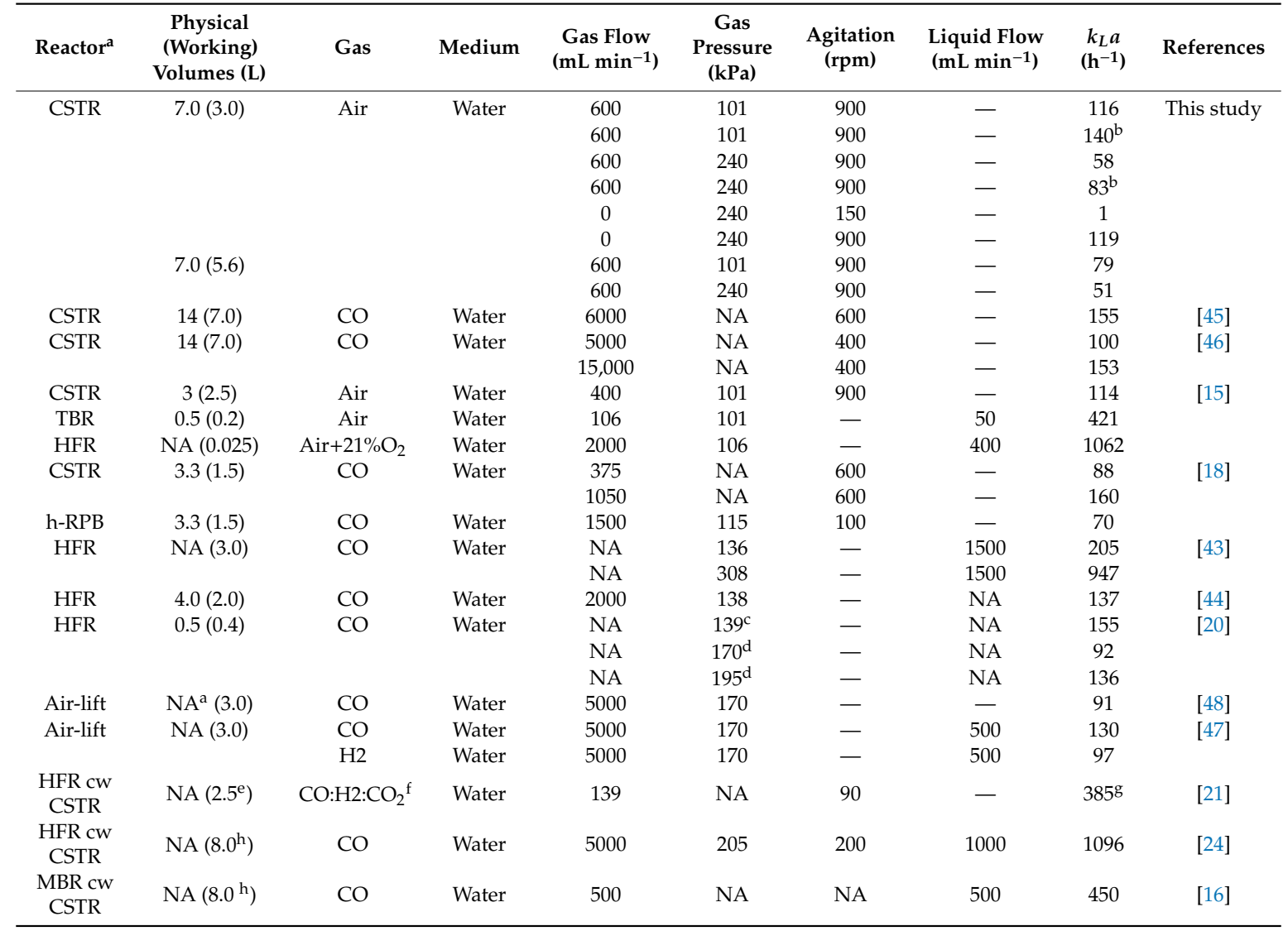

${ }^{a}$ CSTR: continuous stirred tank reactor; HFR: hollow fiber membrane reactor; cw: coupled with; TRB: trickle bed reactor; BCR: bubble column reactor; MBR: monolithic biofilm reactor; h-RPB: horizontal rotating pack bed; NA: not available; ${ }^{\mathrm{b}}$ Headspace flushed with $1000 \mathrm{sccm}$ air for $2 \mathrm{~min}$ before sparging air in water in CSTR; ${ }^{\mathrm{c}}$ \& ${ }^{\mathrm{d}}$ membrane surface area per unit working volume $=62.5 \& 27.5 \mathrm{~m}^{-1}$, respectively; ${ }^{\text {e STR: }} 2.4 \mathrm{~L}$ and HFR: $0.13 \mathrm{~L} ;{ }^{\mathrm{f}} \mathrm{CO}^{\mathrm{C}}: \mathrm{H}_{2}: \mathrm{CO}_{2}$ (50:30:20); ${ }^{\mathrm{g}}$ For $\mathrm{CO}{ }^{\mathrm{h}}$ total volume of both reactors.

\section{Conclusions}

The $k_{L} a$ for $\mathrm{O}_{2}$ was increased by increasing the air flow rates and agitation speeds in the 7-L Bioflo 415 CSTR with the 3 and $5.6 \mathrm{~L}$ working volumes. The increase in headspace pressure decreased the $k_{L} a$ for $\mathrm{O}_{2}$ due to lower volumetric gas flow rate at high pressure. The highest $k_{L} a$ for $\mathrm{O}_{2}$ was $116 \mathrm{~h}^{-1}$, which was obtained at $600 \mathrm{sccm}, 900 \mathrm{rpm}$ and $101 \mathrm{kPa}$ with the $3 \mathrm{~L}$ working volume. Backmixing from the headspace in the non-sparged CSTR at $900 \mathrm{rpm}$ with the $3 \mathrm{~L}$ working volume increased $k_{L} a$. The highest $k_{L} a$ for $\mathrm{O}_{2}$ due to backmixing in the non-sparged CSTR was $119 \mathrm{~h}-1$, attained at $900 \mathrm{rpm}$ and headspace air pressure of $240 \mathrm{kPa}$. A mass transfer model was developed and the model predicted the experimental $k_{L} a$ values for $\mathrm{O}_{2}$ within $10 \%$. Also, the model predicts an increase in $k_{L} a$ for $\mathrm{O}_{2}$ with an increase in the gas flow rate without increasing the power consumption per unit volume $\left(P_{\mathrm{g}} / V_{\mathrm{L}}\right)$. The model was extended to predict the $k_{L} a$ values for syngas components $\mathrm{CO}, \mathrm{CO}_{2}$, and $\mathrm{H}_{2}$, which can provide crucial insights for setting operating conditions in the CSTR to minimize $P_{\mathrm{g}} / V_{\mathrm{L}}$ and increase gas conversion efficiency.

Author Contributions: Conceptualization: H.K.A., K.L. and J.R.P.; methodology: H.K.A., K.L. and J.R.P.; software, K.L. and J.R.P.; validation, K.L. and J.R.P.; data analysis and interpretation: H.K.A., K.L. and J.R.P.; resources: H.K.A., and R.L.H.; writing, review and editing: K.L., H.K.A., J.R.P., X.S., S.M. and R.L.H.; supervision: H.K.A.; funding acquisition: H.K.A. and R.L.H.

Funding: This research was funded by USDA-NIFA Special Research Grant Award USDA-NIFA 34447-20772, Sun Grant Program-South Center No. DOTS59-07-G-00053, USDA-NIFA Project No. OKL03005, and Oklahoma Agricultural Experiment Station. 
Conflicts of Interest: The authors declare no conflict of interest.

\section{Nomenclature}

a Gas-liquid interfacial area per unit volume $\left(\mathrm{m}^{-1}\right)$

$A, B, C$ and $E$ Parameters in Equations (9) and (10)

$C_{\mathrm{L}} \quad$ Bulk dissolved oxygen (DO) concentration in the liquid $\left(\mathrm{mol} \mathrm{m}^{-3}\right)$

$C_{\mathrm{S}} \quad$ Saturated dissolved oxygen (DO) concentration $\left(\mathrm{mol} \mathrm{m}^{-3}\right)$

$D \quad$ Impeller diameter $(\mathrm{m})$

$D_{\mathrm{i}}$ and $D_{\mathrm{j}} \quad$ Diffusivities of gas species $\mathrm{i}$ and $\mathrm{j}$ in water $\left(\mathrm{cm}^{2} \mathrm{~s}^{-1}\right)$

DO Dissolved oxygen (\%)

$g \quad$ Gravitational acceleration $\left(\mathrm{m} \mathrm{s}^{-2}\right)$

$h \quad$ Distance of microsparger from the surface of liquid (m)

$k_{\mathrm{L}} \quad$ Liquid film mass transfer coefficient $\left(\mathrm{m} \mathrm{h}^{-1}\right)$

$k_{\mathrm{L}} \mathrm{a} \quad$ Overall volumetric mass transfer coefficient $\left(\mathrm{h}^{-1}\right)$

$M_{\mathrm{a}} \quad$ Molecular weight of air $\left(\mathrm{g} \mathrm{mol}^{-1}\right)$

MFC Mass flow controller

$n_{\mathrm{a}} \quad$ Molar air flow rate $\left(\mathrm{mol} \mathrm{min}^{-1}\right)$

$N \quad$ Rotation speed of impeller $\left(\mathrm{s}^{-1}\right)$

$N_{\mathrm{A}} \quad$ Aeration number (dimensionless)

$N_{\mathrm{Fr}} \quad$ Froude number (dimensionless)

NIST National Institute of Science and Technology

$N_{\mathrm{p}} \quad$ Power number of single Rushton impeller or marine impeller (dimensionless)

$P_{\mathrm{HS}} \quad$ Headspace pressure $(\mathrm{kPa})$

$P_{\mathrm{HP}} \quad$ Liquid pressure above the microsparger $(\mathrm{kPa})$

$P_{\text {total }} \quad$ Total pressure in the CSTR $(\mathrm{kPa})$

$P_{\mathrm{g}} \quad$ Total impeller power consumption at gassed condition (W)

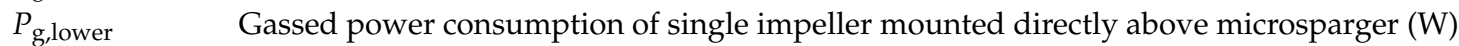

$P_{\text {g,upper }} \quad$ Gassed power consumption for impellers not directly installed above microsparger $(\mathrm{W})$

$P_{\mathrm{g}} / V_{\mathrm{L}} \quad$ Power consumption per unit volume $\left(\mathrm{W} \mathrm{m}^{-3}\right)$

$P_{\mathrm{u}} \quad$ Ungassed power consumption of single impeller (W)

$Q_{\mathrm{g}} \quad$ Volumetric air flow rate at the applied pressure and $37^{\circ} \mathrm{C}\left(\mathrm{mL} \mathrm{min}^{-1}\right)$

$R \quad$ Ideal gas law constant $\left(\mathrm{L} \mathrm{kPa} \mathrm{mol}^{-1} \mathrm{~K}^{-1}\right)$

$t \quad$ Time (h)

T Tank diameter $(\mathrm{m})$

$T_{\text {NIST }} \quad$ NIST standard temperature of $293.15 \mathrm{~K}$

$v_{\mathrm{g}} \quad$ Superficial gas velocity $\left(\mathrm{m} \mathrm{s}^{-1}\right)$

$V_{\mathrm{L}} \quad$ Liquid working volume in CSTR $\left(\mathrm{m}^{3}\right)$

$V_{\text {NIST }} \quad$ Volumetric flow rate of air at standard NIST conditions $\left(\mathrm{m}^{3} \mathrm{~min}^{-1}\right)$

$\alpha, \beta$ and $c \quad$ Model parameters in Equation (11)

$\rho_{\mathrm{a}} \quad$ Air density $\left(\mathrm{kg} \mathrm{m}^{-3}\right)$

$\rho_{\mathrm{w}} \quad$ Water density $\left(\mathrm{kg} \mathrm{m}^{-3}\right)$

$\mu \quad$ Dynamic viscosity of water (Pa s)

\section{References}

1. Ibrahim, M.F.; Ramli, N.; Kamal Bahrin, E.; Abd-Aziz, S. Cellulosic biobutanol by Clostridia: Challenges and improvements. Renew. Sust. Energ. Rev. 2017, 79, 1241-1254. [CrossRef]

2. Devarapalli, M.; Atiyeh, H.K. A review of conversion processes for bioethanol production with a focus on syngas fermentation. Biofuel Res. J. 2015, 2, 268-280.

3. Liu, K.; Atiyeh, H.K.; Pardo-Planas, O.; Ezeji, T.C.; Ujor, V.; Overton, J.C.; Berning, K.; Wilkins, M.R.; Tanner, R.S. Butanol production from hydrothermolysis-pretreated switchgrass: Quantification of inhibitors and detoxification of hydrolyzate. Bioresour. Technol. 2015, 189, 292-301. [CrossRef] [PubMed] 
4. Ramachandriya, K.D.; Kundiyana, D.K.; Sharma, A.M.; Kumar, A.; Atiyeh, H.K.; Huhnke, R.L.; Wilkins, M.R. Critical factors affecting the integration of biomass gasification and syngas fermentation technology. AIMS Bioeng. 2016, 3, 188-210. [CrossRef]

5. Pardo-Planas, O.; Atiyeh, H.K.; Phillips, J.R.; Aichele, C.P.; Mohammad, S. Process simulation of ethanol production from biomass gasification and syngas fermentation. Bioresour. Technol. 2017, 245, 925-932. [CrossRef] [PubMed]

6. Tanner, R.S. Production of ethanol from synthesis gas. In Bioenergy; Wall, J.D., Harwood, C.S., Demain, A.L., Eds.; American Society of Microbiology: Washington, DC, USA, 2008; pp. 147-151.

7. Wilkins, M.R.; Atiyeh, H.K. Microbial production of ethanol from carbon monoxide. Curr. Opin. Biotechnol. 2011, 22, 326-330. [CrossRef] [PubMed]

8. Liu, K.; Atiyeh, H.K.; Tanner, R.S.; Wilkins, M.R.; Huhnke, R.L. Fermentative production of ethanol from syngas using novel moderately alkaliphilic strains of Alkalibaculum bacchi. Bioresour. Technol. 2012, 104, 336-341.

9. $\quad$ Phillips, J.R.; Atiyeh, H.K.; Tanner, R.S.; Torres, J.R.; Saxena, J.; Wilkins, M.R.; Huhnke, R.L. Butanol and hexanol production in Clostridium carboxidivorans syngas fermentation: Medium development and culture techniques. Bioresour. Technol. 2015, 190, 114-121. [CrossRef]

10. Sun, X.; Atiyeh, H.K.; Kumar, A.; Zhang, H.; Tanner, R.S. Biochar enhanced ethanol and butanol production by Clostridium carboxidivorans from syngas. Bioresour. Technol. 2018, 265, 128-138. [CrossRef]

11. Bredwell, M.D.; Srivastava, P.; Worden, R.M. Reactor design issues for synthesis-gas fermentations. Biotechnol. Prog. 1999, 15, 834-844.

12. Klasson, K.T.; Ackerson, M.D.; Clausen, E.C.; Gaddy, J.L. Biological conversion of coal and coal-derived synthesis gas. Fuel 1993, 72, 1673-1678. [CrossRef]

13. Munasinghe, P.C.; Khanal, S.K. Biomass-derived syngas fermentation into biofuels: Opportunities and challenges. Bioresour. Technol. 2010, 101, 5013-5022. [CrossRef] [PubMed]

14. Vega, J.L.; Antorrena, G.M.; Clausen, E.C.; Gaddy, J.L. Study of gaseous substrate fermentations: Carbon monoxide conversion to acetate. 2. Continuous culture. Biotechnol. Bioeng. 1989, 34, 785-793. [CrossRef] [PubMed]

15. Orgill, J.J.; Atiyeh, H.K.; Devarapalli, M.; Phillips, J.R.; Lewis, R.S.; Huhnke, R.L. A comparison of mass transfer coefficients between trickle-bed, hollow fiber membrane and stirred tank reactors. Bioresour. Technol. 2013, 133, 340-346. [CrossRef] [PubMed]

16. Shen, Y.; Brown, R.; Wen, Z. Enhancing mass transfer and ethanol production in syngas fermentation of Clostridium carboxidivorans P7 through a monolithic biofilm reactor. Appl. Energ. 2014, 136, 68-76. [CrossRef]

17. Devarapalli, M.; Atiyeh, H.K.; Phillips, J.R.; Lewis, R.S.; Huhnke, R.L. Ethanol production during semi-continuous syngas fermentation in a trickle bed reactor using Clostridium ragsdalei. Bioresour. Technol. 2016, 209, 56-65. [CrossRef] [PubMed]

18. Shen, Y.; Brown, R.C.; Wen, Z. Syngas fermentation by Clostridium carboxidivorans P7 in a horizontal rotating packed bed biofilm reactor with enhanced ethanol production. Appl. Energ. 2017, 187, 585-594. [CrossRef]

19. Jang, N.; Yasin, M.; Park, S.; Lovitt, R.W.; Chang, I.S. Determination of volumetric gas-liquid mass transfer coefficient of carbon monoxide in a batch cultivation system using kinetic simulations. Bioresour. Technol. 2017, 239, 387-393. [CrossRef] [PubMed]

20. Yasin, M.; Park, S.; Jeong, Y.; Lee, E.Y.; Lee, J.; Chang, I.S. Effect of internal pressure and gas/liquid interface area on the CO mass transfer coefficient using hollow fibre membranes as a high mass transfer gas diffusing system for microbial syngas fermentation. Bioresour. Technol. 2014, 169, 637-643. [CrossRef]

21. Lee, P.-H.; Ni, S.-Q.; Chang, S.-Y.; Sung, S.; Kim, S.-H. Enhancement of carbon monoxide mass transfer using an innovative external hollow fiber membrane (HFM) diffuser for syngas fermentation: Experimental studies and model development. Chem. Eng. J. 2012, 184, 268-277. [CrossRef]

22. Orgill, J.J.; Abboud, M.C.; Atiyeh, H.K.; Devarapalli, M.; Sun, X.; Lewis, R.S. Measurement and prediction of mass transfer coefficients for syngas constituents in a hollow fiber reactor. Bioresour. Technol. 2019, 276, 1-7. [CrossRef] [PubMed]

23. Liew, F.M.; Koöpke, M.; Simpson, S.D. Gas fermentation for commercial biofuels production. In Liquid, Gaseous and Solid Biofuels; Fang, Z., Ed.; InTech: London, UK, 2013; pp. 125-173. 
24. Shen, Y.; Brown, R.; Wen, Z. Syngas fermentation of Clostridium carboxidivoran P7 in a hollow fiber membrane biofilm reactor: Evaluating the mass transfer coefficient and ethanol production performance. Biochem. Eng. J. 2014, 85, 21-29. [CrossRef]

25. Abubackar, H.N.; Veiga, M.C.; Kennes, C. Biological conversion of carbon monoxide: Rich syngas or waste gases to bioethanol. BiofuelsBioprod. Biorefin. 2011, 5, 93-114. [CrossRef]

26. Yasin, M.; Jeong, Y.; Park, S.; Jeong, J.; Lee, E.Y.; Lovitt, R.W.; Kim, B.H.; Lee, J.; Chang, I.S. Microbial synthesis gas utilization and ways to resolve kinetic and mass-transfer limitations. Bioresour. Technol. 2015, 177, 361-374. [CrossRef] [PubMed]

27. Asimakopoulos, K.; Gavala, H.N.; Skiadas, I.V. Reactor systems for syngas fermentation processes: A review. Chem. Eng. J. 2018, 348, 732-744. [CrossRef]

28. Klasson, K.T.; Ackerson, M.D.; Clausen, E.C.; Gaddy, J.L. Bioreactors for synthesis gas fermentations. Resour. Conserv. Recy. 1991, 5, 145-165. [CrossRef]

29. Younesi, H.; Najafpour, G.; Ku Ismail, K.S.; Mohamed, A.R.; Kamaruddin, A.H. Biohydrogen production in a continuous stirred tank bioreactor from synthesis gas by anaerobic photosynthetic bacterium: Rhodopirillum rubrum. Bioresour. Technol. 2008, 99, 2612-2619. [CrossRef]

30. Lopes, M.; Belo, I.; Mota, M. Over-pressurized bioreactors: Application to microbial cell cultures. Biotechnol. Prog. 2014, 30, 767-775. [CrossRef]

31. Lopes, M.; Mota, M.; Belo, I. Oxygen Mass Transfer Rate in a Pressurized Lab-Scale Stirred Bioreactor. Chem. Eng. Technol. 2013, 36, 1779-1784. [CrossRef]

32. Shuler, M.L.; Fikret, K. Bioprocess Engineering: Basic Concepts, 2nd ed.; Prentice Hall: Englewood Cliffs, NJ, USA, 2002; p. 576.

33. Kawase, Y.; Halard, B.; Moo-Young, M. Liquid-phase mass transfer coefficients in bioreactors. Biotechnol. Bioeng. 1992, 39, 1133-1140. [CrossRef]

34. McCabe, W.L.; Smith, J.C. Unit Operations of Chemcial Engineering, 7th ed.; Mcgraw-Hill Inc.: New York, NY, USA, 2005; p. 1007.

35. Bakker, A.; Smith, J.; Myers, K. How to disperse gases in liquids. Chem. Eng. 1994, 101, 98-104.

36. Munson, B.R.; Young, D.F.; Okiishi, T.H.; Huebsch, W.W. Fundamentals of Fluid Mechanics, 6th ed.; Willey: Hoboken, NJ, USA, 2009; p. 784.

37. Lee, J.M. Biochemcial Engineering; Prentice-Hall: Englewood Cliffs, NJ, USA, 1992; p. 240.

38. Blanch, H.W.; Clark, d.S. Biochemcial Engineering; Marcel Dekker, Inc: New York, NY, USA, 1997; p. 702.

39. Ahmed, A.; Cateni, B.G.; Huhnke, R.L.; Lewis, R.S. Effects of biomass-generated producer gas constituents on cell growth, product distribution and hydrogenase activity of Clostridium carboxidivorans $\mathrm{P}^{\mathrm{T}}$. Biomass Bioenergy 2006, 30, 665-672. [CrossRef]

40. Stenberg, O.; Andersson, B. Gas-liquid mass transfer in agitated vessels-II. Modelling of gas-liquid mass transfer. Chem. Eng. Sci. 1988, 43, 725-730. [CrossRef]

41. Liu, K.; Atiyeh, H.K.; Stevenson, B.S.; Tanner, R.S.; Wilkins, M.R.; Huhnke, R.L. Continuous syngas fermentation for the production of ethanol, n-propanol and n-butanol. Bioresour. Technol. 2014, 151, 69-77. [CrossRef] [PubMed]

42. Phillips, J.; Klasson, K.; Clausen, E.; Gaddy, J. Biological production of ethanol from coal synthesis gas. Appl. Biochem. Biotechnol. 1993, 39, 559-571. [CrossRef]

43. Munasinghe, P.C.; Khanal, S.K. Syngas fermentation to biofuel: Evaluation of carbon monoxide mass transfer and analytical modeling using a composite hollow fiber (CHF) membrane bioreactor. Bioresour. Technol. 2012, 122, 130-136. [CrossRef] [PubMed]

44. Jang, N.; Yasin, M.; Kang, H.; Lee, Y.; Park, G.W.; Park, S.; Chang, I.S. Bubble coalescence suppression driven carbon monoxide (CO)-water mass transfer increase by electrolyte addition in a hollow fiber membrane bioreactor (HFMBR) for microbial CO conversion to ethanol. Bioresour. Technol. 2018, 263, 375-384. [CrossRef]

45. Riggs, S.S.; Heindel, T.J. Measuring Carbon Monoxide Gas-Liquid Mass Transfer in a Stirred Tank Reactor for Syngas Fermentation. Biotechnol. Prog. 2006, 22, 903-906. [CrossRef]

46. Ungerman, A.J.; Heindel, T.J. Carbon Monoxide Mass Transfer for Syngas Fermentation in a Stirred Tank Reactor with Dual Impeller Configurations. Biotechnol. Prog. 2007, 23, 613-620. [CrossRef] 
47. Munasinghe, P.C.; Khanal, S.K. Evaluation of hydrogen and carbon monoxide mass transfer and a correlation between the myoglobin-protein bioassay and gas chromatography method for carbon monoxide determination. Rsc Adv. 2014, 4, 37575-37581. [CrossRef]

48. Munasinghe, P.C.; Khanal, S.K. Syngas fermentation to biofuel: Evaluation of carbon monoxide mass transfer coefficient $\left(k_{L} a\right)$ in different reactor configurations. Biotechnol. Prog. 2010, 26, 1616-1621. [CrossRef] [PubMed]

(C) 2019 by the authors. Licensee MDPI, Basel, Switzerland. This article is an open access article distributed under the terms and conditions of the Creative Commons Attribution (CC BY) license (http://creativecommons.org/licenses/by/4.0/). 